MaPan : Jurnal Matematika dan Pembelajaran

p-ISSN: 2354-6883 ; e-ISSN: 2581-172X

Volume 8, No 2, Dec 2020 (264-280)

DOI: https://doi.org/10.24252/mapan.2020v8n2a7

\title{
THE DEVELOPMENT OF PROJECT-BASED LEARNING TOOLS IN GEOMETRIC MATERIAL
}

\author{
Baharuddin'), Ayu Rahyuni Ali'2), Sri Sulasteri3), Ahmad Farham Majid ${ }^{4)}$, Yuspiani ${ }^{5)}$ \\ 1,2,3,4,5Fakultas Tarbiyah dan Keguruan UIN Alauddin Makassar \\ 1,2,3,4,5Kampus II: Jl. H.M. Yasin Limpo Nomor 36 Samata-Gowa \\ E-mail: baharuddin.abbas@uin-alauddin.ac.id1), ayrah218@gmail.com²), srisulasteri@uin- \\ alauddin.ac.id3), ahmad.farham@uin-alauddin.ac.id(4), yuspiani@uin-alauddin.ac.id5)
}

Received September 20, 2020; Revised December 22, 2020; Accepted December 28, 2020

\begin{abstract}
:
The research discusses about project-based on learning tools development in geometric material at class IX MtsN Gowa. This research aims to know the process of the project-based learning tools development which fulfills valid, practical, and effective criteria. The research is Research and Development (R\&D) which uses the development model of ADDIE (Analysis, Design, Development, Implementation, and Evaluation). The development procedure contains 5 steps are: (1) Analysis, (2) Design, (3) Development, (4) Implementation, and (5) Evaluation. The subject of the research is the students at class IX MTsN Gowa which is in one class, the instruments of the research are the validation sheet, the learning outcome test, student and teacher response questionnaire, observation sheet of the learning process, observation sheet of student activity, and observation sheet of learning management. Based on the result of trials obtained that: (1) RPP 3.24 result of validation learning instrument, 3.41 textbooks, and LKPD 3.26 in each value which obtained in the valid category. (2) Practical based on observation result of learning tools practice with an average of 1.97 is in a fully implemented category, teacher response to textbooks and LKPD gave $100 \%$ positive response, the student gave $88.2 \%$ positive responses to the textbooks and while LKPD got $82.3 \%$ positive responses. (3) Effective based on the result of observation management learning got an average of 3.80 with a very good category, student activity in the very good category with an average of $80.56 \%$, the learning outcome test got an average of 83.82 from 100 maximum scores. In conclusion that learning tools that have been tested fill-up the criteria of valid, practical, and effective.
\end{abstract}

Keywords: Mathematics Learning Tools, Project-Based Learning, Geometric Material of Class IX

\section{PENGEMBANGAN PERANGKAT PEMBELAJARAN BERBASIS PROYEK PADA MATERI GEOMETRI}

\begin{abstract}
Abstrak:
Penelitian ini membahas tentang pengembangan perangkat pembelajaran berbasis proyek pada materi geometri kelas IX MTsN Gowa. Penelitian ini bertujuan untuk mengetahui proses pengembangan perangkat pembelajaran berbasis proyek yang memenuhi kriteria valid, praktis, dan efektif. Penelitian ini merupakan penelitian
\end{abstract}


Research and Development (R\&D) yang menggunakan model pengembangan ADDIE (Analysis, Design, Development, Implementation, Evaluate). Prosedur pengembangan terdiri dari 5 tahap yang meliputi: (1) Tahap Analisis (Analysis), (2) Tahap Perencanaan (Design), (3) Tahap Pengembangan (Development), (4) Tahap Penerapan (Implementation), (5) Tahap Evaluasi (Evaluation). Subjek penelitian adalah peserta didik kelas IX MTsN Gowa yang terdiri dari satu kelas. Instrumen penelitian yang digunakan adalah lembar validasi, tes hasil belajar, angket respon peserta didik dan guru, lembar observasi keterlaksanaan pembelajaran, lembar observasi aktivitas peserta didik, serta lembar observasi pengelolaan pembelajaran. Berdasarkan hasil uji coba yang dilakukan diperoleh bahwa: (1) Hasil validasi perangkat pembelajaran RPP 3.24, buku ajar 3.41, dan LKPD 3.26 dengan nilai masing-masing yang diperoleh berada pada kategori valid. (2) Praktis berdasarkan hasil pengamatan keterlaksanaan perangkat pembelajaran dengan nilai rata-rata 1.97 berada pada kategori terlaksana seluruhnya, respon guru terhadap buku ajar dan LKPD memberikan respon positif $100 \%$, respon peserta didik terhadap buku ajar memberikan respon positif $88.2 \%$ sedangkan untuk LKPD memperoleh respon positif $82.3 \%$. (3) Efektif berdasarkan hasil pengamatan pengelolaan pembelajaran memperoleh nilai rata-rata 3.80 dengan kategori sangat baik, aktivitas peserta didik berada dalam kategori sangat baik dengan nilai $80.56 \%$, tes hasil belajar memperoleh nilai rata-rata 83.82 dari skor maksimal 100. Dapat disimpulkan bahwa perangkat pembelajaran yang telah diujicobakan telah memenuhi kriteria valid, praktis, dan efektif.

Kata Kunci: Perangkat Pembelajaran, Pembelajaran Berbasis Proyek, Materi Geometri Kelas IX

How to Cite: Baharuddin, Ali, A. R., Sulasteri, S., Majid, A. F., \& Yuspiani. (2020). The Development of Project-Based Learning Tools in Geometric Material. MaPan : Jurnal $\begin{array}{llll}\text { Matematika dan } & \text { 8(2), 264-280. }\end{array}$ https://doi.org/10.24252/mapan.2020v8n2a7.

\section{INTRODUCTION}

7 he development of the current era triggers a very significant global competition. In confront the world full of competition and challenges,

1 currently be required human resources who have high ability in solving the various problem. Someone who has high ability must be able to think logically, rationally, critically, and creatively (Effendi, 2017: 307). Along with the development era, then education also develops. Development in education could be seen from the many new innovations in education that support the achievement of the desired learning atmosphere to maximize the results of the learning process. This innovation continues to be done to realize the effective learning process. The effective learning process could be seen from the results 
of the students' achievements. One of the supporters of learning achievement is the use of adequate learning devices or tools.

Regarding the creation of active and creative, also independent mathematics learning, learning devices are very important to support the learning process. With the existence of a good learning device, it will help teachers and students to achieve learning objectives coherently and systematically (Astuti \& Wutsqa, 2016: 3). Learning devices are learning support tools that contain learning planning that describes in detail the competencies that students will achieve, learning design that follows a specific learning model syntax, activity guidelines for students, and tools to measure the achievement of student competencies (Kusumaningrum \& Djukri, 2016: 242). Learning tools are important because they are used as guidelines by teachers in the learning process. That way, the learning tools becomes an orientation where the learning objectives are going (Syamsidah, 2018: 54). This is following what Atika, Roza, and Murni (2020: 63) stated the learning tools are used as a teacher's guide in implementing the learning process in class so that the learning process can take place more directed towards the competencies to be achieved. Appropriate learning tools are a very important factor in preparing students to gain learning experiences which means that the learning tools are used as a teacher guide in carrying out the learning process so that it is more focused on the competencies to be achieved. The right learning tool is a very important factor in preparing students to have a good learning experience. The learning tools referred to include learning implementation plans (RPP), student worksheets (LKPD), teacher books (BG), student books (BS), and learning outcomes tests (Santi, Sugiarti, \& Kristiana, 2015: 85). Therefore it is very necessary to develop learning tools in order to meet the needs of students and teachers in teaching and learning mathematics in schools and can achieve the objectives of class administration.

Doli and Armiati (2020: 1) states that learning mathematics is learning about mathematical concepts and structures contained in the material being studied and looking for relationships between the concepts and structures of a material. Mathematics is the subject most disliked by students because mathematics is an abstract science that contains many formulas and symbols which makes it difficult for students to understand mathematics. The statement reveals that mathematics learning is learning about concepts and structures in material and looking for relationships between concepts and structures of the material. Mathematics is a subject that is least liked by 
students because it is an abstract science with many formulas and symbols that make it difficult to understand. One of the characteristics of mathematics is having an abstract object. This abstract nature causes many students to experience difficulties in learning mathematics. This makes mathematics often considered a frightening specter and tends to be considered a difficult subject by most students (Sitorus, 2019: 14).

Based on observations made by researchers in class IX MTsN Gowa found several problems related to the mathematics learning process. The learning tools used are inadequate, this can be seen from the learning implementation plan (RPP) which has been used since 2018 and is not made based on need, textbooks are limited because they are library loan books so students are not free to use the book and are considered convoluted so that it is difficult to understand, and assignments that rarely use worksheets and are limited to tasks in the textbook. Also, according to the narrative of some students, the learning process is still monotonous, centered on the teacher, so that students are less actively involved in the learning process which results in students having difficulty understanding the subject matter. This problem resulted in the low learning outcomes of students, namely only $56 \%$ of students obtained scores above 78 (KKM value). Facts in the field also show that students tend to have difficulty understanding material related to the use of formulas. Based on these problems, the solution offered by the researcher is to develop project-based learning tools on geometry material in grade IX. The development of learning tools is a series of processes or activities carried out to produce a learning device based on existing development theories (Rafiqah, 2013: 95).

Project-based learning or also known as Project-Based Learning (PjBL) is an effective learning model that focuses on creative thinking, problemsolving, and interactions between students and their peers to create and use new knowledge. Project-based learning is innovative student-centered learning and places teachers as motivators and facilitators, where students are given the opportunity to work autonomously constructing their learning (Trianto, 2017: 42-43). The learning model takes place collaboratively in heterogeneous groups. In project-based learning, individual strengths, and the way of learning that is referred to can strengthen teamwork as a whole (Karunia, 2015: 62). Project-based learning is authentic learning that directly engages students with the learning content. This shows that project-based learning is one of the most effective models available to engage students with 
their learning content, and for that reason, project-based learning is now recommended by many educational leaders as best learning practice (Ismail, 2018: 183). From some opinions, it can be concluded that the project-based learning model is an innovative learning model that involves project work where students work independently in constructing their learning and accumulating it in real products (Octariani \& Rambe, 2018: 17).

The types of learning tools that will be developed are Learning Implementation Plans (RPP), Textbooks, and Student Worksheets (LKPD). This is adjusted to the needs of the problems found. The material used in the development of project-based learning tools is geometry material which consists of two chapters, namely congruence and curved side spaces. The selection of geometry material is based on field data which shows that students tend to have difficulty understanding subject matter related to formulas. Besides, according to Sunardi in Fitriani, Hartono, and Purwoko (2010: 55), in the 2004 mathematics curriculum, geometry, and measurement contributed $40 \%$ of competence, the number of competencies or geometry subjects indicated that geometry was an essential part of the curriculum.

Several studies that have been conducted previously, namely research by Durohman, Noto, and Hartono (2018) have conducted research which revealed that project-based learning tools are effective in using high school statistics material. Then the research conducted by Elannor (2017) found that practical and effective project-based learning tools were used in the material of the VII grade triangle area. Furthermore, research from Kusumawati (2017) reveals that project-based learning tools are effectively used to improve students' mathematical communication skills.

Therefore, the development of project-based learning tools on geometry material is important to do with the aim of producing project-based learning tools on geometry material that are valid, practical, and effectively used.

\section{METHODS}

The type of research used in this study is research and development or Research and Development (R\&D) with the ADDIE development model consisting of 5 steps, namely Analysis, Design, Development, Implementation, and Evaluation. The following is the flow of development carried out (Gafur, 2012: 39-40): 


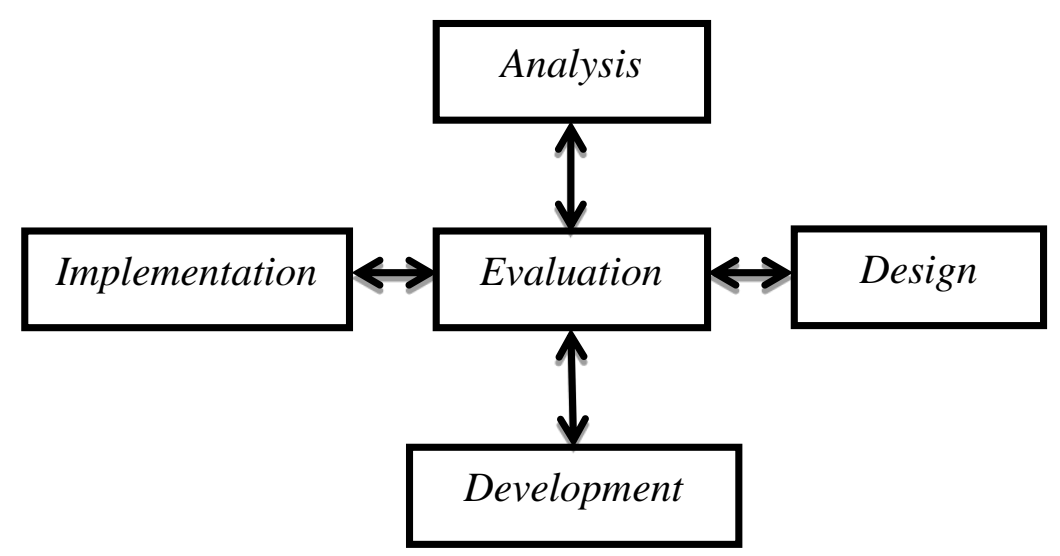

Figure 1. The ADDIE Development Model

The test subjects in this study were students of class IX.5 MTsN Gowa. The data collection instruments used were validation sheets, student and teacher response questionnaires, learning implementation observation sheets, learning management observation sheets, student activity observation sheets, and learning outcome tests. The data analysis technique used was validity data analysis which consisted of validation sheet analysis. The product that has been developed is then validated by a team of experts so that it is feasible to be tested. Practical data analysis techniques consisted of student and teacher response questionnaires and learning implementation observation sheets. If the criteria in the practicality data analysis have been met, then the learning tools can be said to be practically used. The technique of analyzing the effectiveness data consists of the analysis of the learning outcomes test, the analysis of the learning management observation sheet, and the analysis of the student activity observation sheet.

\section{RESULTS AND DISCUSSION}

\section{Project-Based Learning Tools Development Process}

The development of project-based learning tools is developed using the ADDIE development model which consists of 5 steps, namely analysis, design, development, implementation, and evaluation to produce project-based learning tools that are valid, practical, and effective.

The first step in the process of developing project-based learning tools is the analysis step. The main activities carried out at this step are analyzing the background or need for the development of learning media and analyzing the feasibility and requirements for developing learning media (Aminah, 2018: 156). At this step, the researcher analyzes several aspects, namely preliminary 
analysis, analysis of students, material analysis, and task analysis. This analysis step aims to determine the problems that occur so that it is necessary to develop learning tools. At this step of the analysis, information is obtained that the learning tools used are inadequate and have an impact on the low learning outcomes. In the analysis step, the researchers conducted observations and interviews with several students. From the results of the interview, it was found that students have different characteristics. Analysis of students is important to do before grouping them into several groups. This is explained by Hanafy (2017: 119) that the analysis of the characteristics of students is more emphasized on the efforts of grouping students so that the grouping achieves a match between the interests and skills of students with the project tasks to be carried out.

In the material analysis, researchers take material that can be adapted to the learning model used in the development of learning tools, namely projectbased learning models. Ratnasari, Tadjudin, Syazali, Mujib, and Andriani (2018: 51) stated that basically, every model is not better than the other, because each model has its own advantages and disadvantages. However, the model that is closely related with geometry materials is project-based learning, which means that basically all learning models do not have the best level but are applied to each material, and the learning model that is related to geometry material is a project-based learning model. The last analysis is task analysis. The assignments given to students are still limited to practice questions and group assignments in the textbook. Therefore, it is necessary to develop LKPD so that the tasks given are more structured. Based on the description of the results of the analysis, it is necessary to develop learning tools. Therefore, researchers developed project-based learning tools on geometry material for class IX MTsN Gowa.

The next step is the design step. At this step, the researcher makes the initial design of the learning tools, chooses the format to be used, determines the need for learning resources, and compiles learning outcome tests. The main basics of designing a product, namely the purpose of using the product, the users of the resulting product, and a description of the product components and how to use them (Octariani \& Rambe, 2018: 16). The initial design of the learning equipment was made by determining the learning tools to be developed, namely the lesson plans, textbooks, and LKPD. Learning tools are made interrelated by using the characteristics of project-based learning. At this design step, the initial design of the RPP, textbooks, and LKPD has been 
made. The lesson plan is developed by containing project-based learning steps at the core of the lesson and using a project-based learning assessment format. The textbook is designed with an attractive appearance accompanied by pictures that match the learning material, and each sample question is completed with a solution using project-based learning. The textbook is also equipped with small notes consisting of quizzes, math tips, and information on math figures. LKPD consists of project tasks tailored to textbooks. The format of the learning tool contains two chapters of material, namely congruence and curved side space. The need for learning resources contains tools and materials that will be used in the learning process. The learning outcome test is made to measure the ability of students after learning using project-based learning tools and as one of the criteria for determining the effectiveness of the developed learning tools.

The third step is the development step. At this step, the design results are then refined into a learning tool that is ready to be validated. Furthermore, the project-based learning tools that have been compiled are then assessed for their validity by a team of experts consisting of 2 lecturers in the Mathematics Education Department of UIN Alauddin Makassar and a grade IX math teacher at MTsN Gowa. The process of validating the learning tools lasts for two validations with several improvements made based on suggestions from the validator. After the repairs have been made, the results are validated again by the validator. The validation results can be seen in the following table:

Table 1. Expert Validation Results

\begin{tabular}{clccc}
\hline $\begin{array}{c}\text { Validation } \\
\text { Sheet }\end{array}$ & \multicolumn{1}{c}{ Indicator } & Valuation & Information \\
\hline RPP & 1. Aspects of the Content & 3.17 & Valid \\
& 2. Aspect of Presentation & 3.21 & Valid \\
& 3. Aspect of Language & 3.33 & Valid \\
& $\quad$ Average & 3.24 & Valid \\
Textbook & 1. Aspect of the Graphic & 3.4 & Valid \\
& 2. Aspect of Language & 3.25 & Valid \\
& 3. Aspects of the & 3.5 & Very Valid \\
& Content & & Very Valid \\
& 4. Aspect of & 3.5 & Valid \\
\hline
\end{tabular}




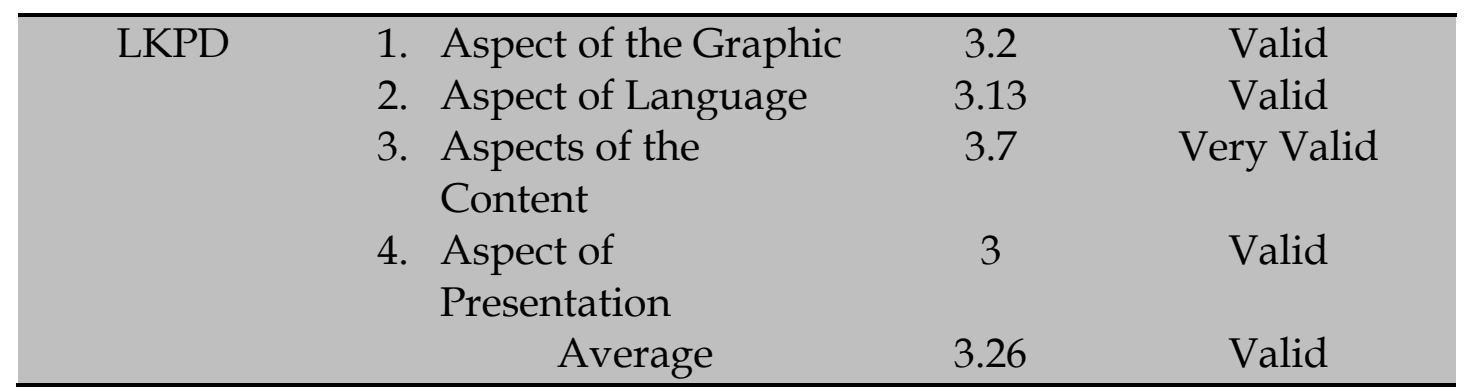

The quantitative validation results in the table above are obtained from the validation sheet that has been filled in by the validator from the Mathematics Education Department of UIN Alauddin Makassar. Based on the data in the table above, it can be seen that the learning tools obtain a valid category where the average value of the lesson plans, textbooks, and student worksheets is in the interval $2.5 \leq \mathrm{M}<3.5$, so it is feasible to be tested. The qualitative validation results were obtained from a grade IX mathematics teacher at MTsN Gowa who provided assessments and suggestions for improvements to the learning tools before they were tested. Apart from the learning tools, the instruments used in the research were also validated by a team of experts. The results of the research instrument validation can be seen in the following table:

Table 2. Results of Research Instrument Validation

\begin{tabular}{lcc}
\hline \multicolumn{1}{c}{ Instrument } & Average Score & Criteria \\
\hline Learning Outcome Test & 3.75 & Very Valid \\
$\begin{array}{l}\text { Student Response } \\
\text { Questionnaires }\end{array}$ & 3.33 & Valid \\
$\begin{array}{l}\text { Teacher Response } \\
\text { Questionnaires }\end{array}$ & 3.33 & Valid \\
$\begin{array}{l}\text { Device Compliance } \\
\text { Observation Sheet }\end{array}$ & 3.47 & Valid \\
$\begin{array}{l}\text { Learning Management } \\
\text { Observation Sheet }\end{array}$ & 3.67 & Very Valid \\
$\begin{array}{l}\text { Student Activity Observation } \\
\text { Sheet }\end{array}$ & 3.5 & Very Valid \\
\multicolumn{1}{c}{ Average } & 3.5 & Very Valid \\
\hline
\end{tabular}

The results of the validation of the research instrument in the table above show that the student response questionnaire, teacher response questionnaire, and observation sheet for the implementation of learning tools are in the valid category, which is in the interval $2.5 \leq \mathrm{M}<3.5$. Whereas for the 
learning outcome test, learning management observation sheet, and student activity observation sheet obtained a very valid category with the average value being in the $3.5 \leq \mathrm{M}<4.0$ interval. Based on the results of this validation, the research instrument is suitable for use in the trial process.

The next step is the trial phase (implementation). Tests were carried out to implement learning tools in the form of learning activities and provide questionnaire sheets to find out students' responses and carried out observation activities during learning activities to determine the practicality of learning activities (Aina \& Paksi, 2020: 367). At this step, the project-based learning tools that have been declared valid are then tried out. The test subjects in this study were class IX.5 MTsN Gowa which consisted of 34 students. The trial phase lasts for 5 meetings with a total of 4 meetings for the learning process and 1 meeting for the learning outcomes test. During the learning process using learning tools, some observers are tasked with observing the learning process and filling out observation sheets for the implementation of the learning tools, student activity observation sheets, and learning management observation sheets. After the learning process is complete, the researcher distributes a response questionnaire to students related to project-based learning tools that have been used in learning. Next, a learning outcome test was conducted to determine the level of ability of students after participating in learning.

The criteria for the practicality of learning tools were obtained through analysis of student response questionnaire data, teacher response questionnaires, and observation sheets of learning tools implementation. The results of the student response questionnaire analysis can be seen in the following table:

Table 3. Results of Student Response Questionnaire Analysis

\begin{tabular}{cccc}
\hline Testing & Aspect & $\begin{array}{c}\text { Positive } \\
\text { Response }\end{array}$ & Presentation \\
\hline \multirow{2}{*}{ Limited } & Book & 30 & $88.2 \%$ \\
& LKPD & 28 & $82.3 \%$ \\
\hline
\end{tabular}

Based on the results of the student response analysis, it was found that $88.2 \%$ of students gave positive responses to textbooks, and $82.3 \%$ of students gave positive responses to LKPD. The positive response obtained cannot be separated from the essence of project-based learning that directs students to explore their own knowledge. This is in accordance with the theory proposed 
by Hanafy (2017: 116) that project-based learning provides opportunities for students to explore content (material) in their own way, and carry out collaborative experiments. Next, the results of the teacher response questionnaire analysis can be seen in the following table:

Table 4. Results of Teacher Response Questionnaire Analysis

\section{Tools Total Average Response Presentation}

\begin{tabular}{ccccc}
\hline Book & 0 & 0.0 & $\mathrm{P}$ & $100 \%$ \\
LKPD & 0 & 0.0 & $\mathrm{P}$ & \\
\hline
\end{tabular}

In the analysis of teacher responses, a percentage of $100 \%$ was obtained for positive $(\mathrm{P})$ responses to textbooks and LKPD. The criteria established to say that teachers and students have a positive response are more than $50 \%$ of teachers or students give a positive response to at least $70 \%$ of the total aspects asked (Arsyad, 2016: 169). Thus, the positive response criteria from teachers and students have been fulfilled.

Analysis of the observation sheet for the implementation of learning tools can be seen in the following table:

Table 5. Results of the Analysis of the Learning Tools Implementation Observation Sheet

\begin{tabular}{lcl}
\hline \multicolumn{1}{c}{ Component } & $\begin{array}{c}\text { Average } \\
\text { Value }\end{array}$ & Criteria \\
\hline Syntax & 2 & Done Completely \\
Social Interaction & 1.97 & Done Completely \\
Reaction Principle & 1.95 & Done Completely \\
Average Value & 1.97 & Done Completely \\
\hline
\end{tabular}

From the results of the analysis of the observation sheet on the implementation of the learning tools above, it can be seen that the projectbased learning tools obtain the entire implemented category. The syntax component obtained an average value of 2 , the social interaction component obtained an average value of 1.97 , and the reaction principle component obtained an average value of 1.95 . The three components are in the $1.5 \leq \mathrm{M} \leq 2$ interval with the fully implemented category. Based on the results of the practical data analysis that have met the practical category, it can be concluded that project-based learning tools in geometry class IX are practically used. 
The criteria for the effectiveness of the learning tools were obtained from the results of the analysis of the learning management observation sheet data, the student activity observation sheet, and the learning outcome test. The results of the analysis of the learning management observation sheet can be seen in the following table:

Table 6. Results of Learning Management Observation Sheet Analysis

\begin{tabular}{cccc}
\hline Category & Aspect & Average value & Criteria \\
\hline Teaching and & Preliminary & 3.79 & Very good \\
Learning & Core activities & 3.83 & Very good \\
Process & Closing & 3.78 & Very good \\
Class Situation & Class Situation & 3.78 & Very good \\
\hline
\end{tabular}

The results of the analysis of the learning management observation sheet as a whole are in very good criteria. Preliminary activities get an average score of 3.79, core activities get a score of 3.83, and closing activities get a score of 3.78. The value obtained in the preliminary, core, and closing activities is at the interval $3.5 \leq \mathrm{KG}<4.5$, so it is in the very good category. For the aspect of the classroom atmosphere, the average score is 3.78 , so it is included in the very good category. Thus it can be said that the management of learning using project-based learning tools is very good.

Furthermore, in the analysis of the effectiveness data, there is an analysis of the activities of students. The activities of students during the learning process were observed by 2 observers. There are 5 aspects that become the assessment of students' activities, namely: 1) observing and understanding the illustrations of problems in student textbooks, 2) writing down the solutions to the problems observed using their own language, 3) students discussing to solve problems in textbooks and LKPD, 4) students present LKPD and project assignments in textbooks and other groups respond, and 5) students provide conclusions or responses after learning. The results of the student activity analysis are shown in the following table: 
Table 7. Results of the Student Activity Observation Sheet Analysis

\begin{tabular}{ccc}
\hline Meeting & $\begin{array}{c}\text { Percentage } \\
\text { Average }\end{array}$ & Criteria \\
\hline 1 & 79.53 & Good \\
2 & 80.82 & Very good \\
3 & 80.59 & Very good \\
4 & 81.29 & Very good \\
Overall & 80.56 & Very good \\
Percentage & & \\
\hline
\end{tabular}

The results of the student activity analysis showed that the activity of students was in the very good category with the average percentage being in the $80 \leq \mathrm{P} \leq 100$ interval so that it was included in the very good category. This means that the activities of students in the learning process are very good. Pratama and Prastyaningrum (2016: 44) states that the activity of the steps of the PjBL (Project-Based Learning) model can provide stimulus to students to improve positive attitudes in learning so that it can affect the students to interest in learning. The statement explains that the steps in project-based learning provide a stimulus to students to be more interested in learning. This is evident because during the learning process students are very enthusiastic and actively involved in learning. This is in accordance with what Sumantri (2016: 78) states that project-based learning provides meaningful activities for students in the form of learning experiences in gaining, understanding, and finding material concepts through project assignments. Furthermore, the results of the analysis of the students' learning outcomes test can be seen in the following table:

Table 8. Analysis Result of Learning Outcomes Test

\begin{tabular}{ccc}
\hline $\begin{array}{c}\text { Completeness } \\
\text { Level }\end{array}$ & Total & Percentage \\
\hline Completed & 30 & 88.24 \\
Not complete & 4 & 11.76 \\
\hline
\end{tabular}

According to Trianto (2017: 241) learning is said to be classically complete if at least $85 \%$ of students get a minimum score of 78 (KKM value). In the analysis of the learning outcome test data, it was found that the overall average score of students was 83.82 . For the percentage of completeness, it was obtained $88.24 \%$ while $11.76 \%$ was declared incomplete with several obstacles. Thus the level of learning completeness is included in the high category and 
can be said to be classically complete. These results show that the percentage of students' learning completeness has increased where previously the percentage of students' learning completeness was only $56 \%$. This cannot be separated from the nature of project-based learning itself which is carried out well. As said by Whatley in Sumarni, Wardani, Sudarmin, and Gupitasari (2016: 157) stated that project-based learning is a form of constructivist and collaborative learning in which the learning process using student-centered learning, which allows students to work together to solve problems, and learn from one another along to build their knowledge. This statement means that project-based learning is basically a form of constructivist and collaborative learning where the learning process is learner-centered which allows students to work together and learn from others in solving problems and growing their knowledge. Based on the description of the results of data analysis on the effectiveness of learning tools, it can be concluded that project-based learning tools were effectively used.

The last step of this development process is the evaluation step. At this step, a summary of the constraints, suggestions, and shortcomings of learning tools obtained during the trial process is then evaluated and improvements are made to perfect the learning tools developed. However, in the development of project-based learning tools, only a few improvements were made to the learning tools.

The purpose of development research is to produce a product based on the findings of a series of trials, for example through individuals, small groups, medium groups, and field trials then revisions, and so on to get adequate or feasible results or products (Punaji, 2016: 281). Thus, the development objective of this research is considered to have been achieved by the existence of a product in the form of feasible learning tools because it has met the criteria of being valid, practical, and effective.

\section{CONCLUSION}

The development of project-based learning tools on geometry class IX has met the criteria of being valid, practical, and effective. Valid criteria are obtained from the results of the validator's assessment with an average score of 3.24 for lesson plans, textbooks get an average of 3.41, and for LKPD 3.26. All learning tools are in the valid category. Based on the validity criteria, project-based learning tools are feasible to use. The practicality of the learning tools was obtained from the student response questionnaire which received a 
positive response percentage of $88.2 \%$ for textbooks and $82.3 \%$ for LKPD, teacher response questionnaires obtained a $100 \%$ percentage for textbooks and LKPD, and the implementation of learning tools was in the implemented category entirely. The practicality of project-based learning tools is obtained from the analysis of learning management which is in the very good category, the analysis of the activities of students is in the very good category, and the learning outcome test gets a completeness percentage of $88.24 \%$. Thus, the project-based learning tools on geometry material for class IX MTsN Gowa are valid, practical, and effectively used.

\section{REFERENCES}

Aina, R. R., \& Paksi, H. P. (2020). Pengembangan perangkat pembelajaran outdor learning dengan media ecobrick pada materi hak dan kewajiban di kelas V SD. JPGSD, 08(02), 364-374. Retrieved from https:// jurnalmahasiswa.unesa.ac.id/index.php/jurnal-penelitian-pgsd/article /view/34446.

Aminah, S. (2018). Implementasi model addie pada education game pembelajaran bahasa Inggris (studi kasus pada SMP Negeri 8 Pagaralam ). Jurnal Ilmiah Betrik : Besemah Teknologi Informasi Dan Komputer, 9(03), 152-162. https:/ / doi.org/10.36050/ betrik.v9i03.41.

Arsyad, N. (2016). Model pembelajaran menumbuh kembangkan kemampuan metakognitif. Makassar: Refleksi.

Astuti, W. D., \& Wutsqa, D. U. (2016). Pengembangan bahan ajar dengan pendekatan project based learning pada materi program linear untuk siswa kelas X SMK. Jurnal Pendidikan Matematika, 5(8). Retrieved from http://journal.student.uny.ac.id/ojs/index.php/pmath/article/view/ 4603.

Atika, N., Roza, Y., \& Murni, A. (2020). Development of learning tools by application of problem based learning models to improve mathematical communication capabilities of sequence and series materials. Journal of Educational Sciences, 4(1), 62-72. https://doi.org/10.31258/jes.4.1.p.6272.

Doli, W., \& Armiati, A. (2020). Development of mathematics learning tools based on realistic mathematics education for vocational high school students. Journal of Physics: Conference Series, 1554. https://doi.org/ 10.1088/1742-6596/1554/1/012021.

Durohman, Noto, M. S., \& Hartono, W. (2018). Pengembangan perangkat project based learning (PjBL) pada materi statistika SMA. Prima: Jurnal Pendidikan Matematika, 2(1), 1-18. https://dx.doi.org/10.31000/prima. v2i1.299.

Effendi, M. (2017). Pembelajaran berbasis proyek (PJBL) untuk 
mengembangkan kemampuan berpikir kritis mahasiswa PGMI IAIN Ponorogo. Cendekia, 15(2), 305-317. https://doi.org/1021154/cendekia. v15i2.1098.

Elannor, C. M. V. A. (2017). Pengembangan perangkat pembelajaran matematika berbasis proyek materi luas siswa kelas VII SMP Institut Indonesia Yogyakarta tahun ajaran 2016/2017 [Universitas Sanata Dharma]. http:/ / people.usd. ac.id/ ydkristanto/index.php/tugas-akhir-mahasiswa/elannor-2017/.

Fitriani, M., Hartono, Y., \& Purwoko. (2010). Pengembangan perangkat pembelajaran matematika dengan pendekatan kuantum di kelas VIII SMP. Jurnal Pendidikan Matematika (JPM), 4(1). https://doi.org/ 10.22342/jpm.4.1.311.

Gafur, A. (2012). Desain Pembelajaran. Yogyakarta: Penerbit Ombak.

Hanafy, S. (2017). Model Pembelajaran. Watampone: Syahadah.

Ismail, R. (2018). Perbandingan keefektifan pembelajaran berbasis proyek dan pembelajaran berbasis masalah ditinjau dari ketercapaian tujuan pembelajaran. PYTHAGORAS: Journal of Mathematics Education, 13(2), 181-188. https:/ / doi.org/10.21831/pg.v13i2.23595.

Karunia. (2015). Penelitian Pendidikan Matematika. PT Refika Aditama.

Kusumaningrum, S., \& Djukri. (2016). Pengembangan perangkat pembelajaran model project based learning (PjBL) untuk meningkatkan keterampilan proses sains dan kreativitas. Jurnal Inovasi Pendidikan IPA, 2(2), 241-251. https:/ / doi.org/10.21831/jipi.v2i2.5557.

Kusumawati, N. (2017). Pengembangan perangkat pembelajaran matematika model project based learning (PBL) untuk meningkatkan kemampuan komunikasi matematik. Jurnal Online Universitas Pekalongan. Retrieved from https://jurnal.unikal.ac.id/index.php/pena/article/viewFile/68 /68.

Octariani, D., \& Rambe, I. H. (2018). Pengembangan bahan ajar berbasis project based learning berbantuan software geogebra. MES: Journal of Mathematics Education and Science, 4(1), 16-21. https://doi.org/10.30743 /mes.v4i1.864.

Pratama, H., \& Prastyaningrum, I. (2016). Pengaruh model pembelajaran project based learning berbantuan media pembelajaran pembangkit listrik tenaga mikrohidro terhadap kemampuan berpikir kritis. Jurnal Penelitian Fisika Dan Aplikasinya (JPFA), 6(2), 44-50. https:/ / dx.doi.org/ 10.26740/jpfa.v6n2.p44-50.

Punaji, S. (2016). Metode penelitian pendidikan dan pengembangan. Jakarta: PT Kharisma Putra Utama.

Rafiqah. (2013). Pengembangan perangkat pembelajaran berbasis konstruktivisme. Makassar: Alauddin University Press.

Ratnasari, N., Tadjudin, N., Syazali, M., Mujib, \& Andriani, S. (2018). Project based learning $(\mathrm{PjBL})$ model on the mathematical representation ability. 
Tadris: Jurnal Keguruan Dan Ilmu Tarbiyah, 3(1), 47-53. https:/ / doi.org/ 10.24042/tadris.v3i1.2535.

Santi, D., Sugiarti, T., \& Kristiana, A. I. (2015). Pengembangan perangkat pembelajaran matematika realistik pada pokok bahasan lingkaran kelas VIII SMP. Kadikma, 6(1). Retrieved from https://jurnal.unej.ac.id/index. php/kadikma/article/view/1831.

Sitorus, E. H. (2019). Pengembangan perangkat pembelajaran berbasis pendekatan saintifik untuk meningkatkankemampuan komunikasi matematis siswa di SMP Negeri 6 Medan. Inspiratif: Jurnal Pendidikan Matematika, 5(1). https://doi.org/10.24114/jpmi.v5i1.13520.

Sumantri, M. (2016). Strategi Pembelajaran Teori dan Praktik di Tingkat Pendidikan Dasar. Depok: PT Rajagrafindo Persada.

Sumarni, W., Wardani, S., Sudarmin, S., \& Gupitasari, D. N. (2016). Project based learning (PBL) to improve psychomotoric skills: A classroom action research. Jurnal Pendidikan IPA Indonesia, 5(2), 157-163. https:/ / doi.org/10.15294/jpii.v5i2.4402.

Syamsidah. (2018). Pengembangan perangkat pembelajaran dengan model kooperatif tipe student teams-achievement divisions (STAD) untuk meningkatkan kreativitas mahasiswadi di jurusan PKK FT UNM. Jurnal MEKOM (Media Komunikasi Pendidikan Kejuruan), 5(2). https://doi.org/ 10.26858/mekom.v5i2.7446.

Trianto. (2017). Mendesain model pembelajaran inovatif progresif dan kontekstual. Jakarta: Prenadamedia Group. 